\title{
O RISCO DA PROPORCIONALIDADE NAS PROVAS ILÍCITAS DO PROCESSO PENAL*
}

THE RISK OF PROPORTIONALITY IN ILLEGAL EVIDENCES IN CRIMINAL PROCEDURE

\section{Fabiano Yuji Takayanagi**}

\begin{abstract}
Resumo:
Trata-se de um estudo com o fito de trazer à tona a discussão acerca do risco da aplicação da proporcionalidade quanto às provas ilícitas no processo penal. Desse modo, a prova, sua importância e a busca da verdade real serão objetos de análise. Explicar-se-á, posteriormente, a proporcionalidade para então adentrar no campo da prova ilícita no processo penal e, assim, correlacionando-os. Por derradeiro, serão expostas críticas sobre os possíveis riscos em aplicar a proporcionalidade em relação às provas ilícitas ferindo o Estado Democrático de Direito, a presunção de inocência e os direitos fundamentais.

Palavras-chave: Provas. Proporcionalidade. Provas ilícitas na Constituição Federal e no processo penal. Riscos de aplicação da proporcionalidade nas provas ilícitas do processo penal.
\end{abstract}

\begin{abstract}
:
The aim of this essay is to promote a discussion about the risk of proportionality relative the prohibited evidences in criminal procedure. Thereby, evidence, its importance and the search of the real truth will be objects of analysis, as well as use of proportionality in the domain of illegal evidence in criminal procedure. Finally, it will be exposed reviews about possible risks in the use of proportionality concerning illegal evidences in the Democratic State of Law, the presumption of innocence and fundamental rights.
\end{abstract}

Keywords: Evidence. Proportionality. Restriction of illegal evidences by the Federal Constitution and by criminal procedure law. Risks in the use of the proportionality for illegal evidence in criminal procedure.

\section{Introdução}

A prova tem suma importância no Direito Processual Penal, uma vez que traz a possibilidade, ao momento de sua análise, da reprodução mais próxima do fato concreto,

\footnotetext{
Agradecimentos:

Agradeço, primeiramente, ao meu grande amigo Antonio Augusto de Campos Neto, que me deu asas ao gosto pela escrita e proporcionou-me conversas do mais elevado nível;

Um especial agradecimento ao Professor Gustavo Henrique Righi Ivahy Badaró por ter sido sempre compreensivo e atencioso ao aclareamento de minhas dúvidas e à introdução de novas e ricas idéias; Por fim, agradeço, imensamente, à Eliza, Yai e Ellen que me estimulam a continuar nessa batalha ao mais alto pico.

** Aluno da Graduação da Faculdade Direito da Universidade de São Paulo.
} 
da verdade única. Serve igualmente para as partes corroborarem tanto acusações como defesas e demonstrar, frente ao órgão jurisdicional invocado, suas pretensões.

Todavia, a Constituição Federal brasileira e o Código de Processo Penal pátrio apresentam certas restrições acerca da obtenção e utilização dessas provas em juízo, declarando inadmissíveis e desentranhando-as dos autos quando forem ilícitas.

Assim sendo, para aqueles que se valem das provas vedadas em nosso ordenamento jurídico, estas não podem sofrer qualquer juízo de valoração, salvo por um caso específico que será devidamente adiante explanado.

Contudo, parte da doutrina, visando incluir as provas ilícitas no decorrer de um processo, tem buscado balizar as proibições impostas pelas leis nos âmbitos do processo penal e da constitucionalidade com base na proporcionalidade. Não-obstante, essa atitude poderá ocasionar sérios riscos ao próprio Estado Democrático de Direito, à presunção de inocência e aos direitos fundamentais.

Vejamos.

1. Prova e verdade no processo penal

Ao se indagar os conceitos de provas, do latim proba, temos várias definições dadas pela Enciclopédia Larousse Cultural, como sendo aquilo que "demonstra, estabelece uma verdade de uma coisa: uma prova convincente; ou tudo o que persuade o espírito de uma verdade ou atesta a existência de um direito"; também algo que atesta ou demonstra algo como seria o caso de um testemunho, um sinal entre outras diversas definições.

Entretanto, devemos nos ater aos conceitos jurídicos de prova que, segundo Ivan Horcaio' em seu Dicionário Jurídico, define como sendo de maneira ampla "todo meio legal, usado no processo, capaz de demonstrar a verdade dos fatos alegados em juízo. A prova deve ter como objetivo principal o convencimento do juiz".

Classicamente, com grande propriedade, C. J. A. Mittermayer ${ }^{2}$ aduz a importância das provas no processo criminal, cuja sentença pronuncia sobre a verdade dos fatos da acusação que tem por base a prova. A acusação teria que fornecer as provas dos fatos e o acusado contestar as provas adversas e sustentar as que o escusam. Haveria um terceiro personagem figurado pelo juiz formador de culpa que estabelece, a seu turno, a prova dos diferentes fatos decisivos do processo. E, por fim, os juízes baseiam suas decisões sobre os fatos que consideram demonstrados. Como se vê, a parte mais importante das

HORCAIO, Ivan. Dicionário Jurídico Referenciado. 1. ed. São Paulo: Primeira Impressão, 2006.

2 MITTERMAYER, C. J. A. Tratado da prova em matéria criminal. Tradução de Alberto Antonio Soares. Rio de Janeiro: Livraria do Editor, 1871. t. 1 e 2. 
prescripções legaes em materia de processo criminal versa sobre a prova, que pode ser definida como sendo um complexo de motivos produtores de certeza.

$\mathrm{O}$ conceito de provas no entendimento de Andrei Vishinski ${ }^{3}$ se dá por meio da citação de Bentham em que se entende por prova "o fato supostamente autêntico, que se considera de motivo" para crer na existência ou inexistência de outro fato. Ainda, cita Bonnier, que em seu sentido mais amplo, a "prova é todo meio direto ou indireto de chegar ao conhecimento dos fatos".

Na definição do grande jurista João Mendes de Almeida Júnior, ${ }^{4}$ em sentido restrito, "a soma dos meios produtores da certeza constitui a prova; mas, em sentido amplo, provas são meios pelos quais a inteligência busca firmar sua adesão ao objeto".

E para o ilustre jurista José Frederico Marques, ${ }^{5}$ prova é o elemento de instrumento para que as partes influam na convicção do magistrado "e o meio de que este serve para averiguar sobre os fatos em que as partes fundamentam suas alegações". É com as provas que se "busca a configuração real dos fatos sobre as questões a serem decididas no processo".

Por fim, Antonio Magalhães Gomes Filho, ${ }^{6}$ com grande razão, define que a prova faria parte, em sentido amplo, aos ramos filosóficos, cujo objetivo nas operações do intelecto é a busca e comunicação do conhecimento verdadeiro podendo-se ter uma vertente objetiva, relativa aos procedimentos investigativos, como também ter uma vertente subjetiva, poderia ou não decorrer da utilização dos procedimentos de investigação.

Gomes Filho afirma que processualmente, o termo prova possui diversos sentidos, quais sejam, "o conjunto de atividades realizadas pelo juiz e pelas partes na reconstrução dos fatos que constituem o suporte das pretensões deduzidas e da própria decisão; os instrumentos pelos quais as informações sobre os fatos são introduzidas no processo (meio de prova); o resultado dessas atividades".

Quanto às verdades no processo penal, sabe-se que rege a busca da verdade real nesse tipo de procedimento.

C. J. A. Mittermayer ${ }^{7}$ ensinava, classicamente, que a verdade é a concordância entre um fato real, e a idéia dele representado em nosso espírito.

\footnotetext{
VISHINSKI, Andrei. A prova judicial no direito soviético. Tradução de Roberto Pereira de Vasconcelos. Rio de Janeiro: Editora Nacional de Direito Ltda., 1957.

4 ALMEIDA JÚNIOR, João Mendes de. Direito judiciário brasileiro. São Paulo: Livraria Freitas Bastos, 1960.

5 MARQUES, José Frederico. Elementos de direito processual penal. 1. ed. Campinas: Bookseller, 1998. v. 2.

6 GOMES FILHO, Antonio Magalhães. Direito à prova no processo penal. São Paulo: Revista dos Tribunais, 1997.

7 MITTERMAYER, C. J. A. Tratado da prova em matéria criminal. Tradução de Alberto Antonio Soares. Rio de Janeiro: Livraria do Editor, 1871. t. 1 e 2.
} 
A doutrina, embora a verdade seja conceito absoluto, logo único, chegou a dividir a verdade em material e formal, sendo que esta se aplicaria ao processo civil e estaria atrelada ao intuito de agilizar a normalização das relações jurídicas conflituosas, sobretudo aquelas concernentes aos litígios patrimoniais. E aquela seria aplicada ao processo penal, porém isso não se confirma, vez que a verdade única e absoluta não pode ser alcançada, apenas uma aproximação dela por meio das provas.

Além do mais, é passível encontrarmos a existência de verdades materiais no processo civil como o caso do art. 130 do CPC em que "Caberá ao juiz, de ofício ou a requerimento da parte, determinar as provas necessárias à instrução do processo, indeferindo as diligências inúteis ou meramente protelatórias".

Nesse sentido, o art. 342 (O juiz pode, de ofício, em qualquer estado do processo, determinar o comparecimento pessoal das partes, a fim de interrogá-las sobre os fatos da causa.), e o art. 355 (O juiz pode ordenar que a parte exiba documento ou coisa, que se ache em seu poder.) do Código de Procedimento Civil também são exemplos da busca da verdade dita material no âmbito do processo civil.

No processo penal, à luz da diferenciação da verdade, pode-se ter a busca de uma verdade formal como quando novas provas, condizentes com a realidade dos fatos, evidenciam a responsabilidade penal do réu que tenha sido absolvido. E transitada em julgada a sentença absolutória, não cabe discutir revisão criminal pro societate como se infere pela leitura do art. 621 e ss. do Código de Processo Penal, de acordo com os dizeres do jurista Marco Antonio de Barros. ${ }^{8}$ Nesse caso, por razões de política criminal privilegia-se a verdade formal.

Nesse mesmo sentido, Marco Antonio de Barros cita os casos do perdão do ofendido, manifestado nas ações penais privadas e a possibilidade de transação penal introduzida pela Lei n. 9.099, de 1995, demonstrando que não prevalece a verdade material.

Sendo assim, modernamente, não temos a distinção de verdades formais ou materiais para determinado procedimento civil ou penal, tem-se somente uma verdade única, logo uma verdade judicial una e livre da dicotomia adotada no passado.

Diz-se, portanto, que se busca uma única verdade, a verdade real no âmbito do processo penal, em que não se tem mais a limitação do magistrado aos critérios legais estabelecidos no antigo sistema de provas legais, que predeterminava os critérios valorativos sob hierarquia estabelecida em lei acerca das provas e deveria, o juiz, seguir estritamente o sistema, mas sim, temos a atuação do julgador que decidirá de forma justa e equidistante na coleta no que entender conveniente ao cabal esclarecimento dos fatos em

8 BARROS, Marco Antonio de. A busca da verdade no processo penal. São Paulo: Revista dos Tribunais, 2002. 
busca da realidade dos fatos, isto é, na sua a identidade entre o objeto e a representação que o sujeito cognoscente faz desse objeto, conforme o ínclito Gustavo Badaró. ${ }^{9}$

Cumpre ressaltar pelos ensinamentos de Frederico Marques ${ }^{10}$ que é inadmissivel, na Justiça Penal, a adoção de que os fins justificam os meios, para assim tentar legitimar-se a procura da verdade através de qualquer fonte probatória, pois permitir qualquer tipo de prática em busca de uma verdade traz sérios riscos à segurança jurídica e a um retorno às práticas do procedimento inquisitivo e injusto em detrimento das diretrizes políticas e jurídicas do processo acusatório.

Diante do explicitado, temos que as provas no processo penal são não só meios de comprovar as verdades alegadas em juízo, como também importantes meios de convencimento do juiz, que sendo imparcial, ${ }^{11}$ julgará à luz do princípio do livre convencimento, ${ }^{12}$ que rege o processo penal, mediante a apresentação das provas e dos fatos ocorridos no passar da sucessão de atos processuais penais sendo sempre obedecidos os princípios constitucionais do contraditório e da ampla defesa.

BADARÓ, Gustavo H. R. Ivahy. Direito processual penal. Rio de Janeiro: Elsevier, 2008. t. 1.

10 MARQUES, José Frederico. Elementos de direito processual penal. 1. ed. Campinas: Bookseller, 1998. v. 2.

11 Embora a Constituição Federal de 1988 não tenha tal princípio expresso, o art. 8.1 da Convenção Americana dos Direitos Humanos declara que todo acusado tem a garantia judicial de ser julgado por um juiz independente e imparcial, sendo, portanto, preceito válido e aplicável no processo penal. Entende Luiz Flávio Gomes como juiz independente seria o juiz que atua sem condicionamento nenhum, apenas sujeitos à lei, ao direito e às bases probatórias da causa sem ingerências ou influências dos outros poderes do Estado ou mesmo dos superiores; o juiz imparcial, por sua vez, está incumbido ao princípio do ne procedat iudex ex officio que visa resguardar o magistrado de qualquer comprometimento psicológico prévio com a prova. (GOMES, Luís Flávio; MAZZUOLI, Valério de Oliveira. Comentários à Convenção Americana sobre Direitos Humanos: Pacto de San José da Costa Rica. 2. ed. São Paulo: Revista dos Tribunais, 2009. v. 4.)

12 O princípio do livre convencimento difere do princípio da íntima convicção do juiz. Este último, por exemplo, serviu de base no sistema probatório do direito soviético. Andrei Vishinski demonstrou que o sistema de provas vincado no princípio da íntima convicção só seria possível com uma base científica sólida, com base em princípios de Direito probatório cientificamente fundamentados. (VISHINSKI, Andrei. A Prova judicial no direito soviético. op. cit.). Walter Coelho define o princípio da íntima convicção como um puro estado subjetivo de certeza, que se basta a si mesmo, independente de qualquer demonstração. (COELHO, Walter. Prova indiciária em matéria criminal. Porto Alegre: Sérgio Antonio Fabris Editor, 1996) O princípio do livre convencimento, de seu lado, explanado, com grande propriedade, pelo jurista Walter Coelho, seria aquele que propicia a livre apreciação da prova, por parte do juiz, mas liberdade essa que, como tudo no Direito, não é limitada e absoluta, mas sim, contrabalançada pela garantia do acusado de ver no" decisum " a razão de decidir. Não apenas "consciência, mas "ciência”,; isto é, motivação racional e livre convicção, num feliz intercâmbio que permita distinguir a liberdade de convencimento do exercício puro, caprichoso e desmedido arbitrio. O juiz é livre, mas, no entanto, está vinculado ao seu juízo, de forma a satisfazer não só as partes, em concreto, mas a sociedade em que vivem os seus jurisdicionados. (COELHO, Walter. op. cit.). Por fim, o livre convencimento, nos ensinamentos de José Frederico Marques, é lógico e motivado (MARQUES, José Frederico. op. cit.), portanto, não se pode o magistrado decidir sem expor seus fundamentos e motivações em atendimento ao disposto no art. 93, inciso IX da Carta Magna. Isso torna o juiz mais público e limita todo o seu poder em relação ao caso de desnecessidade de motivação de suas decisões. Assim, ele está livre de preconceitos legais na aferição das provas, todavia não está isento da motivação de sua sentença. Isso impede o arbítrio por parte do magistrado e o impõe à motivação de seu convencimento publicamente para o cumprimento de sua função em aplicar a lei devidamente em busca do equilíbrio da justiça. 
É o que temos no art. 155 do Código de Processo Penal (alterado pela Lei n. 11.690 de 2008, antigo art. 157), cuja transcrição nos remete ao seguinte texto: “O juiz formará sua convicção pela livre apreciação da prova produzida em contraditório judicial, não podendo fundamentar sua decisão exclusivamente nos elementos informativos colhidos na investigação, ressalvadas as provas cautelares, não repetíveis e antecipadas". Isso demonstra a essencialidade das provas no processo penal dando um sentido basilar nas decisões judiciais, bem como uma maneira de proteção ou ataque seja do autor, seja do réu diante de uma lide.

Dessa forma, sendo o processo penal uma divergência de opiniões fáticas, é por meio das provas que se busca a reconstrução histórica dos fatos passados ${ }^{13}$ de ambos os lados da lide a fim de se chegar à verdade, que será posta ao livre convencimento do magistrado e este, por sua vez, julgará e realizará a justiça caso a caso, buscando uma sentença lógica e motivada mais próxima de uma correta verificação dos fatos, dando às partes paridades de armas para suas defesas invocando o contraditório e a ampla defesa respeitando-se tanto os fins quanto os meios utilizados.

\section{Do princípio, da razoabilidade e da proporcionalidade}

Ivan Horcaio em seu Dicionário Jurídico ${ }^{14}$ define que princípio nada mais é que "regra, preceito, razão primária. Proposição, verdade geral, em que se apóiam outras verdades".

Josef Esser, citado por Tiago Cintra Essado, ${ }^{15}$ afirma que princípios seriam "normas que estabelecem fundamentos para que determinado mandamento seja encontrado". Seriam, portanto, os princípios, pilares para o surgimento de regras.

Citando Karl Larenz, Essado define que princípios seriam “como normas de grande relevância para o ordenamento jurídico, na medida em que estabelecem

\footnotetext{
13 O professor Antonio Magalhães Gomes Filho coloca a possível analogia da posição do juiz como um historiador, isto é, ambos buscam reviver no presente fatos do passado por meio das provas. Todavia, distinções devem ser feitas: a primeira se dá enquanto o historiador tem mais liberdade na delimitação do fragmento da realidade passada sobre a qual versará sua pesquisa, o juiz, de seu lado, está vinculado ao objeto de postulações alheias, portanto, não pode arbitrariamente valer-se de seu poder e investigar por sua vontade afora dos limites permitidos pelo direito; a segunda está na obrigatoriedade do juiz chegar à conclusão qualquer que seja o material probatório trazido, ao passo que, o historiador pode ter ilimitado alargamento de sua pesquisa caso não esteja convencido; por fim, terceiro, juiz e historiador possuem métodos distintos no que diz respeito à colheita de material informativo como na avaliação dos dados obtidos. O primeiro está ligado a critérios legais de obtenção e regulação das provas, já o segundo pode adotar, por exemplo, seus próprios critérios, ou de sua comunidade científica. (GOMES FILHO, Antonio Magalhães. Direito à Prova no Processo Penal. São Paulo: Revista dos Tribunais, 1997)

14 HORCAIO, Ivan. Dicionário Jurídico Referenciado. 1. ed. São Paulo: Primeira Impressão, 2006.

15 ESSADO, Tiago Cintra. O princípio da proporcionalidade no direito penal. Porto Alegre: Sérgio Antonio Fabris Editor, 2008.
} 
fundamentos normativos para a interpretação e aplicação do Direito, deles decorrendo, direta ou indiretamente, normas de comportamento".

Todavia, cumpre ressaltar que as regras são diferentes dos princípios principalmente em relação à sua maneira de solução de conflitos como podemos confirmar a seguir. Vejamos.

Segundo o ilustre jurista Robert Alexy, ${ }^{16}$ quando temos um conflito, por exemplo, entre duas regras, somente poderíamos ter sua solução se introduzíssemos, em uma delas, uma cláusula de exceção que elimine o conflito, ou se pelo menos uma delas seja declarada inválida.

Alexy demonstra sua teoria com o caso de uma proibição de se sair da sala de aula enquanto o sinal não batesse e o dever de se sair da sala de aula caso o alarme de incêndio soasse. A segunda regra é a chamada cláusula de exceção que deve ser incorporada à primeira, portanto, se ocorrer do alarme de incêndio soar, a cláusula de exceção que passa a ser a regra, mas ambas, embora contraditórias entre si, podem coexistir por meio da inclusão da regra de exceção à principal.

Entretanto, se não for possível a coexistência das regras e em havendo a regra de exceção inclusa na regra principal, uma delas deve ser extirpada do ordenamento jurídico, deve ser declarada inválida.

De outro lado, quando nos encontramos em uma colisão de princípios, nos ensinamentos de Robert Alexy, há uma solução diversa do caso do confronto de regras. Em havendo princípios contraditórios entre si, um dos princípios deverá ceder, sem ser declarado inválido, nem introduzido sob a forma de cláusula de exceção.

Geralmente, os princípios têm pesos diferentes, logo o de maior peso predomina sobre o de menor. Assim, as regras têm seu conflito no âmbito da validade, os princípios na dimensão do peso.

$\mathrm{Na}$ teoria de Alexy acerca da lei de colisão, é ilustrada por meio do caso em que havia uma incapacidade para participar de audiência processual a qual "tratava da admissibilidade de realização de uma audiência com a presença de um acusado que, devido à tensão desse tipo de procedimento, corria o risco de sofrer um derrame cerebral ou um infarto". Dessa forma, o tribunal alemão viu-se em uma dicotomia entre o dever estatal na aplicação efetiva do direito penal e o interesse do acusado na garantia de seus direitos constitucionalmente garantidos, que a Constituição alemã obriga o Estado.

A solução nesse caso deve ser feita por meio de sopesamento entre interesses conflitantes. Assim, haver-se-ia interesses sob o mesmo nível abstrato e dever-se-ia escolher o interesse que tivesse maior peso no caso concreto.

16 ALEXY, Robert. Teoria dos direitos fundamentais. Tradução de Luís Virgílio Afonso da Silva. São Paulo: Malheiros, 2008. 
Agora, quanto ao sopesamento de normas de direito fundamental atribuídas, teríamos que duas normas, se isoladas, levariam a resultados contraditórios entre si, porém nenhuma delas é inválida, nem tem precedência absoluta sobre a outra. O que vale, segundo Robert Alexy, “depende da forma como será decidida a precedência entre elas sob a luz do caso concreto". Assim, como mais uma variedade como objetos de sopesamento, deverá ser acrescentada a dos valores constitucionais.

Portanto, chega-se à conclusão que a aplicação das teorias dos princípios é passada também à teoria das normas de direitos fundamentais, poderemos, assim, prosseguir à explicação da teoria da proporcionalidade.

Cumpre esclarecer, antes de adentrarmos no campo da proporcionalidade, a diferenciação terminológica e doutrinária em relação à razoabilidade.

O ínclito Humberto Ávila ${ }^{17}$ conceitua a razoabilidade de três formas possíveis: como equidade; como congruência; e como equivalência.

Como eqüidade, entende-se que é um instrumento com o objetivo de determinar que as circunstâncias de fatos sejam consideradas com a presunção de estarem dentro da normalidade. Sua atuação encontra-se na interpretação dos fatos descritos em regras jurídicas e serve como meio de preservar a eficácia dos princípios axiologicamente sobrejacentes. É um instrumento metodológico para demonstrar que a incidência da norma é condição necessária mas não suficiente para sua aplicação. E para tal, o caso concreto deve adequar-se à generalização da norma geral. A razoabilidade atua na interpretação das regras gerais como decorrência do princípio da justiça.

Como congruência, a razoabilidade, para Humberto Ávila, exige a harmonização das normas com suas condições externas de aplicação, isto é, exige a recorrência a um suporte empírico existente e uma relação de congruência entre o critério de diferenciação escolhido e a medida adotada.

Como equivalência, Ávila expõe que temos a necessidade de uma relação de equivalência entre a medida adotada e o critério que a dimensiona. Ou seja, aplica-se, por exemplo, no caso do Direito Penal em que as penas devem ser fixadas de acordo com a culpabilidade do agente, logo a culpa é critério para a fixação da pena a ser cumprida, assim, ela deve ser correspondente à culpa.

Entendido os possíveis sentidos de razoabilidade, pode-se adentrar na esfera da proporcionalidade.

Pois bem, para Robert Alexy ${ }^{18}$ há certa conexão entre a teoria dos princípios e a máxima de proporcionalidade e esta possui suas três máximas parciais, quais sejam, a da

\footnotetext{
17 ÁVILA, Humberto. Teoria dos princípios: da definição à aplicação dos princípios jurídicos. 9. ed. São Paulo: Malheiros, 2009.

18 ALEXY, Robert. Teoria dos direitos fundamentais. Tradução de Luís Virgílio Afonso da Silva. São Paulo:
} 
adequação; da necessidade (mandamento do meio menor gravoso); e da proporcionalidade em sentido estrito (mandamento do sopesamento propriamente dito).

A proporcionalidade em sentido estrito decorre da relativização em face das possibilidades jurídicas. Ocorre, segundo Alexy, que quando uma norma de direito fundamental com caráter de princípio colide com um princípio antagônico, a possibilidade jurídica para a realização dessa norma depende do princípio antagônico. A decisão é alcançada por meio do sopesamento nos termos da lei de colisão.

A necessidade significa, na explicação de Thiago Pierobom Ávila, ${ }^{19}$ a utilização, entre as várias medidas aptas, da mais benigna, mas suave ou menos restritiva. É também denominada intervenção mínima, ou alternativa menos gravosa, ou subsidiariedade, necessitando a comparação das alternativas aptas a otimizar a menor lesão possível. E a adequação seria a idoneidade do meio utilizado para a persecução do fim desejado.

O princípio da proporcionalidade entende Paulo Bonavides, citado por Tiago Essado, que a base do princípio da proporcionalidade está na relação entre os fins pretendidos e o fundamento da intervenção, para existência do controle desta, evitando o excesso. Infere-se, assim, que a proporcionalidade tem sua função de guardar e proteger os direitos fundamentais.

O professor Luís Virgílio Afonso da Silva, citado por Belize Câmara Correia, afirma que a proporcionalidade teve sua criação e desenvolvimento na jurisprudência do Tribunal Constitucional Alemão, sendo integrada por subelementos objetivos independentes, aplicados em uma ordem pré-definida - adequação, necessidade e proporcionalidade em sentido estrito - possuindo uma estrutura racionalmente definida.

Acrescenta Belize Correia que a proporcionalidade incide no balanceamento de interesses, recorrendo a instrumentos objetivos e específicos de análise - adequação, necessidade e proporcionalidade em sentido estrito.

Cumpre esclarecer que a proporcionalidade não é um princípio que se choca com outras normas-princípio, e sim, um mecanismo ou método de sopesamento entre outros princípios que se encontrem numa determinada situação, em momento de antagonismo.

Na Doutrina brasileira a proporcionalidade tem sua aplicação em momentos, por exemplo, de colisão entre direitos fundamentais, e é forma de se evitar decisões abusivas e injustas, trazendo compatibilidade entre meio e fins.

A proporcionalidade exige, do órgão incumbido de aplicar o Direito em decisões, a necessidade de recorrer a critérios valorativos, que são externos à literalidade

Malheiros, 2008.

19 ÁVILA, Thiago Pierobom. Provas ilicitas e proporcionalidade. Rio de Janeiro: Lumen Juris, 2007. 
da lei, pois deve-se ponderar em um conflito de normas. Normas estas que em casos máximos representam dois ou mais direitos ou garantias fundamentais, assim, o aplicador do Direito deve-se valer de parcimônia e sopesar qual o sentido a se seguir evitando medidas injustas.

A doutrina expõe a distinção entre proporcionalidade e razoabilidade, embora suas proximidades, muitas vezes, remetam aos princípios como sinônimos, e pelos julgados do Supremo Tribunal Federal, dá-se a entender que o órgão máximo do Judiciário entende como equivalentes, como se verifica pela jurista Belize Câmara Correia, ${ }^{20}$ na análise, por exemplo, do HC 76.060/SC. Primeira Turma. Relator: Min. Sepúlveda Pertence, cuja transcrição nos remete a “(...) hipótese na qual, à luz do princípio da proporcionalidade ou da razoabilidade, se impõe evitar a afronta à dignidade pessoal, que (...)"; na Medida Cautelar na ADIn 1910/DF, cuja transcrição nos remete a “(...) ao contrário, desafiam a medida da razoabilidade ou da proporcionalidade, caracterizam privilégios inconstitucionais (...)"; no HC 77.003/PE. Segunda Turma. Relator: Min. Marco Aurélio, cuja transcrição nos remete a (...). Uma vez verificada a insignificância jurídica do ato apontado como delituoso, impõe-se o trancamento da ação penal por falta de justa causa. A isto direcionam os princípios da razoabilidade e da proporcionalidade. (...)". Deixando claro que o STF tem seu entendimento em aproximar ambos os conceitos a ponto de expô-los em um mesmo patamar, sem distinções.

Diante do exposto, adotar-se-á a proporcionalidade como sendo um procedimento, um método de resolução nas colisões dos princípios, permanece a um plano acima desses princípios não entrando em confronto com eles nos casos concretos.

É, portanto, aceitar a definição de De Plácido e Silva ${ }^{21}$ sobre a proporcionalidade: refere-se à adequação "que deve existir entre a ação e o resultado ou entre os valores protegidos pelas normas jurídicas. É o critério de interpretação axiológica, quando se põem em confronto valores diversos, devendo o intérprete optar pelo valor que se mostra com maior densidade ou importância".

\section{As provas ilícitas no Processo Penal}

Quando tratamos de provas ilícitas, devemos primeiramente distinguilas das provas ilegítimas. Estas, segundo o ínclito jurista Gustavo Badaró, ${ }^{22}$ seriam as produzidas com violação de normas processuais, qual seja, na oitiva de uma testemunha sem dar direito às partes de fazerem reperguntas, por exemplo.

20 CORREIA, Belize Câmara. O controle de constitucionalidade dos tipo penais incriminadores à luz da proporcionalidade. Porto Alegre: Sérgio Antonio Faris Editor, 2009.

21 DE PLÁCIDO E SILVA. Vocabulário Jurídico. 24. ed. Rio de Janeiro: Forense, 2004.

22 BADARÓ, Gustavo H. R. Ivahy. Direito processual penal. Rio de Janeiro: Elsevier, 2008. t. 1. 
Nesse mesmo sentido, Walter Coelho ${ }^{23}$ afirma que a prova será ilegítima a partir do momento em que conflitar com uma norma de caráter processual, assim, teríamos uma prova à deriva do ordenamento jurídico processual e que, no momento de discordância e desrespeito ao direito instrumental, produziu-se de forma ilegítima.

Adalberto Aranha ${ }^{24}$ deixa claro que a ofensa ao direito quando da produção da prova, de sua introdução ao processo, ferindo uma norma processual é o caso de prova ilegítima.

Assim, temos que as provas ilegítimas violam as normas de direito processual e são colhidas dentro do processo, isto é, no momento em que são produzidas em juízo, como, por exemplo, no caso de interrogar o acusado sem a presença de um advogado, ou ouvir um advogado acerca de fatos que ele tem conhecimento em decorrência de sua função e se ele depuser, o depoimento será uma prova ilegítima devido à sua função. ${ }^{25}$ São, portanto, casos endoprocessuais.

As provas ilegítimas, no Direito Processual Penal, aos dizeres do professor Antonio Magalhães Gomes Filho, ${ }^{26}$ são nulas, logo suas produções podem ser renovadas para se adequarem às regras processuais pertinentes. E o descumprimento da lei processual incumbe à nulidade do ato de formação da prova e impõe a necessidade de sua renovação, nos termos do que determina o art. 573, caput, ${ }^{27}$ do Código de Procedimento Penal.

As provas ilícitas, de seu lado, são aquelas que violam as regras de direito material, que ocorrem em momento de sua obtenção. Esta, por sua vez, no entendimento de Walter Coelho, ocorre com ofensa ao ferimento do direito substancial, assegurado em lei ordinária ou até mesmo na órbita constitucional.

Para Irajá Pereira Messias, ${ }^{28}$ a prova ilícita é toda aquela que violar direitos impostergáveis do homem, como a honra, a dignidade, a inviolabilidade de domicílio, de correspondência e de comunicações, e o direito à integridade física. Nesse sentido, é exemplo de prova ilícita aquela que foi obtida mediante tortura, ferindo a dignidade da pessoa humana.

A nova redação do art. 157 do Código de Processo Penal aduz que são “inadmissíveis, devendo ser desentranhadas do processo, as provas ilícitas, assim entendidas

23 WALTER, Coelho. Prova indiciária em matéria criminal. Porto Alegre: Sérgio Antonio Fabris Editor, 1996.

24 ARANHA, Adalberto José Q. T. de Camargo. Da prova no processo penal. 7. ed. São Paulo: Saraiva, 2006.

25 Art. 207. São proibidas de depor as pessoas que, em razão de função, ministério, ofício ou profissão, devam guardar segredo, salvo se, desobrigadas pela parte interessada, quiserem dar o seu testemunho. (Código de Processo Penal).

26 GOMES FILHO, Antonio Magalhães; PRADO, Geraldo; BADARÓ, Gustavo Henrique Righi Ivahi; Santos, Leandro Galuzzi dos; BOTTINI, Pierpaolo Cruz. As reformas no processo penal. São Paulo: Revista dos Tribunais, 2008.

${ }^{27}$ Art. 573. Os atos, cuja nulidade não tiver sido sanada, na forma dos artigos anteriores, serão renovados ou retificados.

28 MESSIAS, Irajá Pereira. Da prova penal. 3. ed. Campinas: Impactus Editora, 2006. 
as obtidas em violação a normas constitucionais ou legais”. Dessa forma, as provas ilícitas, diferentemente das ilegítimas, que podem ter sua renovação posteriormente à declaração de sua nulidade, não podem ser renovadas, devem ser excluídas, desentranhadas do processo, sem qualquer valoração e manifestação acerca da prova ilícita pelo juiz da causa.

A mencionada distinção é o entendimento do Supremo Tribunal Federal corroborado pelo julgamento do HC n. 81.167/BA, cujo relator, o Ministro Gilmar Mendes, diferenciando que prova ilícita é aquela que viola norma ou princípio de direito material e prova ilegítima é aquela que ofende normas ou princípios de direito processual.

Portanto, quanto à distinção no plano da natureza da norma violada, segundo Luiz Francisco Avolio, ${ }^{29}$ temos a diferenciação em relação ao momento de sua transgressão: a prova ilegítima tem sua ilegalidade ocorrida no momento de sua produção no processo, já a prova ilícita pressupõe uma violação no momento da colheita da prova, anterior ou concomitante ao processo, mas sempre exterior a este processo.

Todavia, ambos os tipos de provas mencionados fazem parte do conjunto de provas vedadas pelo ordenamento jurídico que são, nas palavras de Badaró, ${ }^{30}$ pertencentes ao gênero das provas ilegais.

Ademais, na Carta Republicana, em seu art. $5^{\circ}$, inciso LVI, declara-se que: "são inadmissíveis, no processo, as provas obtidas por meio ilícitos". Dessa forma, não são aceitas as provas decorrentes à violação do direito material ou de garantias constitucionais vigentes.

Aduz Alexandre de Moraes $^{31}$ que "a inadmissibilidade das provas ilícitas no processo deriva da posição preferente dos direitos fundamentais no ordenamento jurídico, tornando impossível a violação de uma liberdade pública para obtenção de qualquer prova".

As Mesas de Processo Penal da Faculdade de Direito da Universidade de São Paulo ${ }^{32}$ adotaram posições de inadmissão de qualquer prova obtida por meio ilícitos. Isso resultou em Súmulas com a de n. 48 declarando que "Denominam-se ilícitas as provas colhidas com infringência a normas e princípios de direito material; a de número 49, São processualmente inadmissíveis as provas que infringem normas e princípios constitucionais, ainda quando forem relevantes e pertinentes, e mesmo sem cominação processual expressa"; a de n. 50, "Podem ser utilizadas no processo penal as provas ilicitamente colhidas, que beneficiem a defesa".

\footnotetext{
29 AVOLIO, Luiz Francisco Torquato. Provas ilicitas: interceptações telefônicas e gravações clandestinas. São Paulo: Revista dos Tribunais, 1995.

30 BADARÓ, Gustavo H. R. Ivahy. Direito processual penal. Rio de Janeiro: Elsevier, 2008. t. 1.

31 MORAES, Alexandre de. Direitos humanos fundamentais: teoria geral. 8. ed. São Paulo: Atlas, 2007.

32 GRINOVER, Ada Pellegrini; FERNANDES, Antonio Scarance; GOMES FILHO, Antonio Magalhães. As nulidades no processo penal. 9. ed. São Paulo: Revista dos Tribunais, 2006
} 
Dessa forma, não se pode valer-se de provas ilícitas e expô-las ao livre convencimento de um juiz para apuração de uma verdade, vez que há indubitavelmente os direitos e garantias fundamentais da pessoa humana proibindo tal ato. De nada adiantaria princípios constitucionais e processuais penais, bem como os Direitos Humanos positivados na Carta Republicana sob a forma de Direitos e Garantias Fundamentais se não fossem seguidos, obedecidos.

Assim, as provas ilícitas são inadmissíveis pela Carta Republicana, logo não podem sofrer qualquer juízo de valor, apenas devem ser excluídas, e, portanto, desentranhadas do processo, ${ }^{33}$ em se tratando do processo penal, de acordo com a nova redação do art. 157 do Código de Procedimento Penal. Vivemos em um Estado Democrático de Direito e para tal, regras, princípios, normas não podem ser violados para satisfação de um interesse ilegal.

\subsection{As provas ilícitas à luz da proporcionalidade}

Entende a doutrina moderna brasileira, que visa à utilização da proporcionalidade, a necessidade de maior flexibilidade para correção de distorções da rigidez, acerca da inadmissibilidade de provas ilícitas, para não causar danos graves a um indivíduo de maneira injusta utilizando-se da proporcionalidade.

Os defensores da aplicação do princípio dizem que somente em casos extremos e de grande gravidade poder-se-ia valer das provas ilícitas, sopesando-se os valores em contradição e em debate. Afirma-se ser que a admissão de uma prova obtida por meio ilícito um princípio meramente relativo, que poderia, portanto, ser violado desde que esteja em jogo e em posição contraria um princípio ao qual se atribui igual ou maior valor, conforme expõe o jurista Adalberto Aranha. ${ }^{34}$

\footnotetext{
33 Na nova redação do art. 157 do Código de Processo Penal temos que as provas inadmissíveis deverão ser desentranhadas do processo e no parágrafo $3^{\circ}$ do mesmo artigo que: Preclusa a decisão de desentranhamento da prova declarada inadmissivel, esta será inutilizada por decisão judicial, facultado às partes acompanhar o incidente. Nesse caso, a inutilização das provas inadmitidas, é fator de discórdia, pois o Professor Antonio Magalhães Gomes Filho, com razão, ressalta que uma prova declarada ilícita num determinado processo possa vir a ser utilizada validamente em outro. Seria o caso de se utilizar essa prova ilícita do processo "A", mas validamente lícita no processo "B" em defesa do acusado no caso de uma prova ilícita pro reo em uma revisão criminal. Acrescenta o doutro mestre que se foi afastado proposta importante do Projeto de Lei 4.205/2001 que dispunha: Preclusa a decisão de desentranhamento da prova declarada ilícita, serão tomadas as providencias para o arquivamento sigiloso em cartório. O que seria nesse contexto muito mais plausível de se fazer. (GOMES FILHO, Antonio Magalhães; PRADO, Geraldo; BADARÓ, Gustavo Henrique Righi Ivahi; Santos, Leandro Galuzzi dos; BOTTINI, Pierpaolo Cruz. As Reformas no Processo Penal - Coordenação: Maria Thereza Rocha de Assis Moura. São Paulo: Revista dos Tribunais, 2008).

34 ARANHA, Adalberto José Q. T. de Camargo. Da prova no processo penal. 7. ed. 3 tir. São Paulo: Saraiva, 2008.
} 
O professor Antonio Magalhães Gomes Filho ${ }^{35}$ explica que a teoria da proporcionalidade para superação das vedações probatórias teria suas raízes inspirada na jurisprudência do BGH alemão. Defendia-se que a justiça penal seria interesse do Estado de Direito e em certos casos, poder-se-ia justificar o sacrifício dos direitos individuais, logo seria legítima a derrogação de certas regras de exclusão de prova, existentes para proteção ao indivíduo, em nome da prevenção e repressão das formas mais graves de criminalidade.

Assim, a teoria que visa admitir as provas ilícitas em um processo, excluindose a exceção da prova ilícita pro reo, valendo-se da proporcionalidade tem respaldo na defesa do intuito de correção de "possíveis distorções a que a rigidez da exclusão poderia levar em casos de excepcional gravidade". ${ }^{36}$

Dessa forma, temos a prevalência do interesse predominante em que importa uma ponderação entre valores subjetivos e o de maior importância, à luz do entendimento do julgador, será incorporado e nessa incorporação, possivelmente, poder-se-ia ter uma prova ilícita.

Todavia, a professora Ada Pellegrini Grinover ${ }^{37}$ ensejando sobre o assunto afirmou que "a exceção aos princípios de exclusão da prova ilícita, baseada num equilíbrio de valores fundamentais conflitantes, ou seja, no princípio da proporcionalidade, pode, evidentemente, tornar-se perigosa, por sua própria subjetividade".

É de se inferir que a proporcionalidade pode se tornar um risco à sociedade na medida em que é usado de forma a se buscar a verdade real no processo penal violando bens e direitos de forma descoordenada e ilimitada. Isso seria incorporar um sistema repressivo, cuja principal forma de se obter confissões, verdades seria por meio do massacre indiscriminado das individualidades e liberdades. É ter fins justificados pelos meios.

Não se pode, portanto, desvirtuar a proporcionalidade que, hoje, pode ser aceita no caso da proporcionalidade pro reo para usá-la de forma arbitrária. Deve-se reconhecer o subjetivismo que se tem quando se usa tal princípio, pois há o sopesamento de valores, estes relativos a cada indivíduo, trazendo, pois, resultados desproporcionais em se tratando de ponderação de valores íntimos.

\footnotetext{
35 GOMES FILHO, Antonio Magalhães. Direito à prova no processo penal. São Paulo: Revista dos Tribunais, 1997.

36 GRINOVER, Ada Pellegrini; FERNANDES, Antonio Scarance; GOMES FILHO, Antonio Magalhães. As nulidades no processo penal. 9. ed. São Paulo: Revista dos Tribunais, 2006.

37 GRINOVER, Ada Pellegrini. Liberdades públicas e processo penal: as interceptações telefônicas. São Paulo: Saraiva, 1976.
} 


\subsection{Caso excepcional de aceitação de provas ilícitas}

Embora se tenha os dispostos no art. $5^{\circ}, \mathrm{LVI}^{38}$ da Carta Magna e o art. $157^{39}$ do Código de Procedimento Penal a necessária inadmissão, no primeiro caso, e desentranhamento do processo, no segundo caso, das provas ilícitas, a doutrina e jurisprudência é pacífica em defender apenas uma exceção acerca desses preceitos, é o caso da aceitação das provas ilícitas pro reo.

A doutrina ${ }^{40}$ mostra-se praticamente unânime quanto ao reconhecimento de utilização da proporcionalidade quanto ao caso de provas ilícitas infringindo direitos fundamentais do próprio réu ou de terceiros exclusivamente nas provas ilícitas em prol do acusado.

A jurisprudência pátria entende como possível somente a admissão e aplicação da proporcionalidade, segundo o ínclito constitucionalista Alexandre de Moraes, ${ }^{41}$ no caso da proporcionalidade pro reo (RJTJSP $\left.138 / 526\right)^{42}$ em que a ilicitude é eliminada por causas excludentes de ilicitude ou em prol do princípio da inocência (STF $-1^{\mathrm{a}} \mathrm{T}-\mathrm{HC}$ no. 74.678/DF - rel. Min. Moreira Alves - Informativo STF no. 75).

Nesse contexto, o jurista Thiago Ávila ${ }^{43}$ concorda e aduz que não restariam dúvidas quanto à utilização de uma prova ilícita para comprovar a inocência de um acusado. Assim, deve-se ponderar entre a ampla defesa, princípio constitucional para buscar a verdade e inocentar o réu acusado injustamente e outra garantia constitucional que proíbe, veda a admissão de provas obtidas ilicitamente.

38 Art. $5^{\circ}$, LVI - são inadmissíveis, no processo, as provas obtidas por meios ilícitos.

39 Art. 157 - São inadmissíveis, devendo ser desentranhadas do processo, as provas ilícitas, assim entendidas as obtidas em violação a normas constitucionais ou legais.

40 Nesse sentido temos grandes nomes como Ada Pellegrini Grinover, Antonio Scarance Fernandes, Antonio Magalhães Gomes Filho (As nulidades no processo penal. 9. ed. São Paulo: Revista dos Tribunais, 2006); Luiz Francisco Torquato Avolio (Provas ilícitas: interceptações telefônicas e gravações clandestinas. São Paulo: Revista dos Tribunais, 1995).

41 MORAES, Alexandre de. Direitos humanos fundamentais: teoria geral. 8. ed. São Paulo: Atlas, 2007.

42 Gravação Telefônica e Prova Lícita. Considera-se prova lícita, desde que haja causa excludente da antijuridicidade da ação (p. ex.: legítima defesa em caso de extorsão), a gravação telefônica feita por terceiro com autorização de um dos interlocutores sem o conhecimento do outro. Não há, na hipótese, ofensa aos arts. 151, II ('Quem indevidamente divulga, transmite a outrem ou utiliza abusivamente... conversão telefônica entre outras pessoas') e 153 ('Divulgar alguém, sem justa causa, conteúdo de documento particular ou de correspondência confidencial, de que é destinatário ou detentor, e cuja divulgação possa produzir dano a outrem'), todos do CP. Com esse entendimento, a Turma afastou o argumento de afronta ao art. 5. ${ }^{\circ}$, XII, da CF ('XII - é inviolável o sigilo das comunicações telefônicas, salvo por ordem judicial, nas hipóteses e na forma que a lei estabelecer...') e indeferiu o pedido de habeas corpus interposto contra acórdão do STJ, que mantivera a decisão do TJSP. (Ação Penal 307-DF) (grifos à parte)

43 ÁVILA, Thiago Pierobom. Provas ilícitas e proporcionalidade. Rio de Janeiro: Lumen Juris, 2007. 
Ainda afirma que, não se permitir utilizar as provas como meio de comprovar a inocência de um réu acusado injustamente, é ferir com a política criminal do Estado Democrático de Direito.

Dessa forma, o que temos em certos casos em que a ilicitude das provas inadmitidas pela Carta Republicana é afastada, seria quando um indivíduo ultrapassa a esfera limítrofe de sua liberdade e invade a outra e, esta, por sua vez, agindo em legítima defesa de suas liberdades acaba se valendo de meios que não são aceitos por lei como o caso de uma gravação realizada pela vítima comprovando um crime de extorsão sem ordem judicial, conforme exige o art. $5^{\circ}$, inciso XII da Carta Magna, por exemplo. Não temos no caso uma violação da intimidade por parte da vítima, mas, sim, uma legítima defesa de seus direitos humanos fundamentais, logo há ausência de ilicitude da prova afastando o art. $5^{\circ}$, inciso LVI da Constituição Federal.

Entretanto, um caso excepcional foi o julgado STF 1.T. HC 70.814/SP - Rel. Min. Celso de Mello, que aceitou a prova obtida por meios ilícitos através da interceptação de correspondência de preso realizada pela administração penitenciária, em razões de segurança pública, de disciplina prisional, de preservação da ordem jurídica. Motivou que não se pode proteger-se com princípios, tal como a inviolabilidade de correspondências, para cometer ilícitos, isto é, não se pode valer-se das liberdades públicas como forma de proteger-se nas práticas de atividades ilícitas, nem tampouco para excluir ou diminuir a responsabilidade penal ou civil por atos criminosos, o que feriria um Estado Democrático de Direito.

Assim, é evidente que o Supremo Tribunal Federal usou-se da ponderação de princípios, entre o principio da inviolabilidade da correspondência e o da supremacia do interesse público, para formular sua decisão de aceitar a prova obtida ilicitamente, mas veja bem, tais casos são excepcionais. É certo que o órgão máximo do Judiciário deve se valer de ponderação em suas decisões, vez que tem repercussão nas esferas públicas e grande influência na vida de toda sociedade, porém quanto ao caso específico das provas ilícitas, devemos analisar cuidadosamente para não termos um Estado repressivo a ponto de intervir a qualquer tempo na vida dos indivíduos, invadindo suas intimidades, violando as inviolabilidades.

Dessa forma, admite-se a aplicação da proporcionalidade como forma do exercício do direito de defesa, essencial no processo penal e garantido constitucionalmente por meio do princípio do favor rei.

\subsection{As provas ilícitas por derivação}

A doutrina das provas ilícitas por derivação tem sua origem no julgamento feito pela Suprema Corte norte-americana, em 1920, no caso Silverthone Lumber Co. 
vs. U.S., que formulou a chamada fruit of the poisonous tree doctrine ou taint doctrine, cuja regra é a exclusão de toda prova contaminada, envenenada por uma investigação inconstitucional.

De acordo com o professor Antonio Magalhães Gomes Filho, ${ }^{44}$ o tema também tem sido objeto de consideração pela doutrina e jurisprudência alemãs dando sua manifestação sob o nome de efeito à distância em relação à prova vedada. Assim, o BGH entende que se um acusado é confrontado com o resultado de uma gravação ilícita, as declarações dai resultantes não podem ser valoradas; mas, se nas mesmas condições, menciona fatos novos, estes já não constituem prova ilícita.

Em sentido contrário, segundo Gössel citado pelo professor Gomes Filho, “o tribunal tem reconhecido um efeito à distancia em casos de interceptação telefônica quando através de uma operação autorizada para apuração de um dos crimes catalogados, descobrese uma prova de um outro crime, não relacionado entre os que admitem interceptação".

De qualquer modo, percebe-se que inevitavelmente haveria certa contaminação das provas posteriores ligadas à primária ilícita, não-somente pela critério da causalidade como também pela finalidade com que são estabelecidas as suas proibições analisadas.

A jurisprudência norte-americana, segundo Antonio Magalhães Gomes Filho, ${ }^{45}$ não tem sua posição absoluta quanto à teoria dos frutos da árvore envenenada, pois abre exceção em dois casos de provas derivadas das ilícitas, quais sejam, a da independent source e da inevitable discovery, que se entende poder aproveitar as provas derivadas.

Pela exceção da independet source, a chamada fonte independente, suas raízes encontram-se no caso julgado pela Suprema Corte envolvendo Bynum vs. U.S. no ano de 1960 .

Basicamente o caso envolvia um acusado preso de forma ilegal, que teve suas impressões digitais colhidas comprovando seu relacionamento com um roubo, entretanto, as provas colhidas foram consideradas derivadas de uma prisão ilegal, logo excluídas. Em um segundo julgamento, a acusação ofereceu outras impressões digitais, antigas, vindas de arquivos do FBI, por essa razão, foi reconhecida a validade da prova, pois não havia conexão com a prisão ilegal.

Pela exceção inevitable discovery, tendo o caso paradigma de Nix vs. Williams II, no ano de 1984, a Suprema Corte americana entendeu que a doutrina da árvore

44 GOMES FILHO, Antonio Magalhães. Direito à prova no processo penal. São Paulo: Revista dos Tribunais, 1997.

45 GOMES FILHO, Antonio Magalhães; PRADO, Geraldo; BADARÓ, Gustavo Henrique Righi Ivahi; Santos, Leandro Galuzzi dos; BOTTINI, Pierpaolo Cruz. As reformas no processo penal. São Paulo: Revista dos Tribunais, 2008. 
dos frutos envenenados não se aplicaria em situações em que a prova fosse inevitavelmente descoberta por uma investigação legal.

O caso julgado remetia a um acusado que havia matado uma criança e ele submetido a meios ilícitos de obtenção de confissão, informou o paradeiro do corpo. Assim, embora a confissão tenha sido de forma ilegal, a Corte entendeu que devido à atuação de 200 voluntários na busca desse corpo, foi válida a inevitável descoberta e não havia relação com a ilegalidade. Houve, portanto, a exclusão da relação da causalidade, logo não haveria derivação da prova inconstitucional.

As duas exceções expostas foram base para o legislador brasileiro na nova redação do art. 157 do Código de Processo Penal, incluído pela Lei n. 11.690 de 2008, como veremos a seguir.

\subsection{A nova redação do Código de Processo Penal quanto às provas derivadas}

O parágrafo primeiro do art. 157, incluído pela Lei n. 11.690, de 2008, acrescentou o seguinte ao Código de Processo Penal: São também inadmissíveis as provas derivadas das ilícitas, "salvo quando não evidenciado o nexo de causalidade entre umas e outras, ou quando as derivadas puderem ser obtidas por uma fonte independente das primeiras". (grifos à parte).

A segunda parte do referido parágrafo, influenciada pela jurisprudência americana, tentou reproduzir as exceções de independent source e inevitable discovery nos casos em que a prova derivada poder-se-ia ser aproveitada, vejamos.

Quando o legislador trouxe "quando não evidenciado o nexo de causalidade entre umas e outras", tentou exprimir que a falta de nexo de causalidade entre uma prova e outra, poder-se-ia ter o aproveitamento da prova não advinda da ilícita, ora, isso é evidente, pois provada a inexistência de vínculo entre a primeira prova ilícita e a obtenção da segunda, intui-se que não se trata de caso de prova derivada, portanto, a segunda prova seria perfeitamente admissível.

O professor Antonio Magalhães Gomes Filho ${ }^{46}$ afirma que "apesar de redundante, essa parte do texto legal não parece trazer inconveniente na sua aplicação".

Intrigante é a parte em que o legislador expôs: "quando as derivadas puderem ser obtidas por uma fonte independente das primeiras", pois tentou trazer a exceção americana independent source, mas de forma equivocada.

\footnotetext{
46 GOMES FILHO, Antonio Magalhães; PRADO, Geraldo; BADARÓ, Gustavo Henrique Righi Ivahi; Santos, Leandro Galuzzi dos; BOTTINI, Pierpaolo Cruz. As reformas no processo penal - Coordenação: Maria Thereza Rocha de Assis Moura. São Paulo: Revista dos Tribunais, 2008.
} 
O ínclito jurista Antonio Magalhães Gomes Filho relata que houve um afastamento da "noção original fixada na jurisprudência americana, que, como visto, supõe que o dado probatório possua duas origens, uma lícita e outra ilícita, subsistindo como elemento de convicção válido, mesmo com a supressão de fonte legal".

E ainda com a forma verbal condicional puderem ser obtidas, deixa a dúvida de que bastaria a possibilidade da prova ser obtida por meio lícito para que fosse afastada a sua contaminação pela ilegalidade inicial.

Gomes Filho aponta que o parágrafo segundo do mesmo art. 157, ao definir o que seria fonte independente, qual seja, "considera-se fonte independente aquela que por si só, seguindo os trâmites típicos e de praxe, próprios da investigação ou instrução criminal, seria capaz de conduzir ao fato objeto da prova", traria certa insegurança para que, sob esse fundamento, toda e qualquer prova derivada de outra ilícita venha a ser convalidada.

É o caso de uma confissão obtida mediante tortura e no caso do indivíduo torturado indicando o local em que se encontraria a prova documental, mediante um mandado judicial e cumprimento de todas as formalidades, o documento é apreendido.

Assim, à luz da doutrina vigente, os documentos apreendidos são tão ilícitos quanto à confissão, vez que fere cabalmente um direito e garantia fundamental, um direito material, entretanto, pela disposição do $\S 2^{\circ}$ do art. 157, introduzido pela Lei n. 11.690 de 2008, bastaria que houvesse uma possibilidade da obtenção de forma regular da prova derivada que tudo estaria nos conformes da legalidade. É trazer uma grande insegurança jurídica e violar uma garantia constitucional do art. $5^{\circ}$, inciso LVI, da Carta Magna.

Houve, portanto, um equívoco por parte do legislador ao transpor o conceito de inevitable discovery da jurisprudência americana para a legislação brasileira em descoberta inevitável e fonte independente, pois no sistema americano, seriam as circunstâncias especiais do caso concreto que permitem considerar que a prova seria inevitavelmente obtida, mesmo se suprimida a fonte ilícita. ${ }^{47}$

Infere-se, pois, que pela redação do parágrafo segundo do art. 157 temos uma inconstitucionalidade.

4. Dos possíveis riscos de aplicação da proporcionalidade em relação às provas ilícitas

4.1. Do ferimento ao Estado Democrático de Direito

4.1.1. O Estado Democrático de Direito

47 GOMES FILHO, Antonio Magalhães; PRADO, Geraldo; BADARÓ, Gustavo Henrique Righi Ivahi; Santos, Leandro Galuzzi dos; BOTTINI, Pierpaolo Cruz. As Reformas no Processo Penal - Coordenação: Maria Thereza Rocha de Assis Moura. São Paulo: Revista dos Tribunais, 2008. 
Importa ressaltar que o regime político-jurídico assentado em nossa Constituição Republicana, de 1988, é o de Estado Democrático de Direito. Por esse motivo, será necessária uma análise histórica precedente à explicação do conceito a ser abordado antes de se correlacionar os riscos possíveis da aplicação da proporcionalidade no âmbito das provas ilícitas no Estado Democrático de Direito.

Pois bem, a democracia foi uma criação dos gregos, ${ }^{48}$ em Atenas, fizeramna sob a forma de uma democracia política direta, isto é, os cidadãos gregos, conhecidos como eupátridas (aristocratas), reunidos, tomavam decisões acerca da cidade, a polis, porém era privilégio de poucos, pois escravos, metecos (povo estrangeiro habitante em Atenas), não eram considerados cidadãos.

No século XVIII, o conceito de democracia passou a ter maior alcance às demais camadas da população, diferente do modelo grego, graças ao Jean Jacques Rousseau, pensador iluminista, que concedeu à democracia uma teoria sob o nome de teoria da soberania popular.

Rousseau em seu livro Contrato Social, segundo Francisco C. Weffort, ${ }^{49}$ tem o intuito de expor a existência de uma espécie de pacto social, pacto legítimo, entre homens que após terem perdido sua liberdade natural, ganham em troca a liberdade civil. E ainda, no processo de legitimação desse pacto social, é essencial a igualdade das partes contratantes, não havendo onerosidade a nenhuma delas, apenas a equivalência de condição contratual.

Próximo passo pós-legitimação do pacto social, seguindo as explicações de Weffort, é a vontade de representação na política. Assim, há necessidade de formação de um governo sob a forma de um corpo administrativo do Estado, porém como órgão limitado pelo poder do povo. A soberania viria do povo e não do poder do Estado.

Entretanto, quanto à representação, diz Rousseau que no "momento em que um povo se dá representantes, não é mais livre, não mais existe”. Assim, afirma que uma vontade não pode ser representada e o exercício da vontade geral através de representantes significa uma sobreposição de vontades.

Todavia, o filósofo francês, conforme Weffort, reconhecera a necessidade de representantes no governo, mas sem qualquer descuido de vigilância sobre eles, pois a tendência era agir em nome de si mesmos e não em nome dos seus representados, logo concluiu a imprescindibilidade de troca desses representantes com frequência.

É baseado no ideal de Rousseau acerca da soberania popular que a Carta Magna tem em seu Título I, parte Dos Princípios Fundamentais, no parágrafo único do

48 ENCICLOPÉDIA LAROUSSE CULTURAL. São Paulo: Nova Cultural, 1998.

49 WEFFORT, Francisco C. Os clássicos da politica. 13.ed. São Paulo: Ática, 2005. v. 1. 
art. $1^{\circ}$ o seguinte: "Todo o poder emana do povo, que o exerce por meio de representantes eleitos ou diretamente, nos termos desta Constituição".

Definido o conceito e o ideal de democracia que subsiste no ordenamento brasileiro, é de suma importância entender como se estabelece o atual o Estado Democrático de Direito.

O grande jurista José Afonso da Silva ${ }^{50}$ afirma que o princípio da legalidade ${ }^{51}$ é o princípio basilar do Estado Democrático de Direito. E ainda como todo Estado de Direito, está sujeito à força da lei, lei esta que tem o fim de realizar a igualdade, bem como trazer a igualização das condições dos socialmente desiguais.

Dessa forma, aduz o ínclito jurista que "a lei não deve ficar numa esfera puramente normativa, não pode ser apenas lei de arbitragem, pois precisa influir na realidade social. E se a Constituição se abre para as transformações políticas, econômicas e sociais que a sociedade brasileira requer, a lei se elevará de importância, na medida em que, sendo fundamental expressão do direito positivo, caracteriza-se como desdobramento necessário do conteúdo da Constituição e aí exerce função transformadora da sociedade, impondo mudanças sociais democráticas, ainda que possa" continuar a desempenhar uma função conservadora, garantindo a sobrevivência de valores socialmente aceitos.

Além disso, José Afonso da Silva também elencou princípios que devem reger um Estado Democrático de Direito, quais sejam, o princípio da constitucionalidade, que há legitimidade de uma Constituição rígida, portanto, tem maiores dificuldades para sua alteração em relação às demais normas jurídicas estatais, e é fruto da vontade popular, ainda que exerça sua supremacia sobre qualquer norma do ordenamento jurídico inferior a ela; o princípio democrático em que se deve constituir uma democracia representativa e participativa, pluralista, e que seja a garantia geral da vigência e eficácia dos direitos fundamentais; o respeito ao sistema dos direitos fundamentais que seriam os Direitos

50 SILVA, José Afonso da. Curso de direito constitucional positivo. 24. ed. São Paulo: Malheiros, 2005.

51 Define Ivan Horcaio como sendo o princípio da legalidade: modalidade em que não há crime, nem pena, sem prévia cominação legal. O seu enunciado latino ("nullum crimen, nulla poena sine lege") foi criado por Anselsmo Feuerbach, todavia encontram-se manifestações semelhantes no Direito romano. A Lei Valéria condicionou a execução da pena de morte, decretado pelo magistrado, à confirmação do povo. Na Idade Média, os jurisconsultos também registraram preocupação nesse sentido. (...) A Magna Carta, em 1215, deixou expresso: "Ninguém poderá ser detido, preso ou despojado de seus bens, costumes e liberdades, senão em virtude de julgamento por seus pares segundo as leis do país"(cláusula 48). A Declaração dos Direitos do Homem e do Cidadão, votada em 2 de outubro de 1789, diz: "A lei não deve estabelecer senão penas estritamente e evidentemente necessárias e ninguém pode ser castigado senão em virtude de uma lei estabelecida e promulgada anteriormente ao delito e legalmente aplicada"(VIII). No Direito Penal brasileiro, foi registrado na Constituição Imperial (1824); dai passou para o Código Criminal do Império (1830) e comparece em todos os textos congêneres posteriores. O Código Penal estatui enfaticamente: "Não há crime sem lei anterior que o defina. Não há pena sem prévia cominação legal”. Dessa forma, o Direito Penal brasileiro, como a maioria das legislações, é escrito, inadmitida a aplicação analógica quando prejudicar o réu (....)(HORCAIO, Ivan. Dicionário jurídico referenciado. 1. ed. São Paulo: Primeira Impressão, 2006). 
Humanos positivados, compreendidos em individuais, coletivos, sociais e culturais; o princípio da justiça social seria a realização da democracia social e cultural, sem avançar significativamente rumo à democracia econômica, conforme aduzimos pelo artigo 170, caput, e o 193, princípio da ordem econômica e social; o princípio da igualdade elencado no art. $5^{\circ}$, caput e I; o princípio da divisão de poderes do art. $2^{\circ}$ e da independência do juiz do art. 95; o princípio da legalidade do art. $5^{\circ}$, inciso II; e por fim, o princípio da segurança jurídica do art. $5^{\circ}$, incisos XXXVI e LXXIII.

Temos no art. $3^{\circ}$ da Carta Magna os objetivos fundamentais que visam alcançar o Estado Democrático de Direito, quais sejam, “construir uma sociedade livre, justa e solidária; garantir o desenvolvimento nacional; erradicar a pobreza e a marginalização e reduzir as desigualdades sociais e regionais; e promover o bem de todos, sem preconceitos de origem, raça, sexo, cor, idade e quaisquer outras formas de discriminação”.

Assim, a lei acompanha as necessidades de uma coletividade e não deve representar o irreal, isto é, apenas no âmbito escrito, cumpre estar intimamente ligada à realidade para tentar suprir o imprescindível a todos. A força, o império de uma Lei Constitucional tem capacidade de mudar toda uma sociedade, desde dogmas, até o convívio interpessoal, por essa razão, deve-se constantemente analisar as leis tanto infraconstitucionais e constitucionais quanto às suas adequações à realidade social e democrática de um Estado Democrático de Direito.

4.1.2. A aplicação da proporcionalidade nas provas ilícitas e o ferimento ao Estado Democrático de Direito

A constante aplicação de um princípio de proporcionalidade para as provas ilícitas a fim de serem recepcionadas não como provas ilegais, mas como válidas, excluindo-se os casos excepcionais, é trazer a possibilidade de um Estado visionando uma possível irregularidade na validade de determinadas provas, antecedendo-se com o intuito de torná-las legais, é, portanto, abrir uma ferida ao tão defendido Estado Democrático de Direito.

É, em outras palavras, tornar um Estado policial, portanto é investigar o momento pré-fato jurídico, isto é, tornar um Estado regulador, violador de direitos e garantias individuais, das individualidades, das intimidades.

Podemos tomar como exemplo de um Estado repressor e policialesco mencionando o art. 24 da Lei das Contravenções Penais (LCP), instituída pelo DecretoLei n. 3.688, de 1941 .

Urge salientar que a LCP foi instituída em época de ditadura, o Estado Novo, cuja Constituição em vigor era a Constituição outorgada, de 1937, apelidada de "A 
Polaca" ${ }^{52}$ e baseada na Constituição autoritária da Polônia, imposta ao país em 1926 pelo general Pilsudski.

Era uma Carta que continha restrições, intervenções estatais delimitando liberdades, hoje, defendidas, vejamos, por exemplo, o artigo 122, 15, “a”, que tratava dos Direitos e Garantias Individuais, cuja lei podia prescrever "com o fim de garantir a paz, a ordem e a segurança pública, a censura prévia da Imprensa, do teatro, do cinematógrafo, da radiodifusão, facultando à autoridade competente proibir a circulação, a difusão ou a representação". (grifos à parte). Também o caso do artigo 175 da mesma Carta de 37, que previa a renovação do mandato do Presidente da República mediante a realização de um plebiscito, nunca realizado. Era evidente a presença de um Estado regulador, proibitivo.

Nas palavras do grande jurista José Afonso da Silva, ${ }^{53}$ a "Carta de 1937 não teve, porém, aplicação regular. Muitos de seus dispositivos permaneceram letra morta. Houve ditadura pura e simples, com todo o Poder Executivo e Legislativo concentrando nas mãos do Presidente da República, que legislava por via de decretos-leis que ele próprio depois aplicava, como órgão do Executivo".

Entendido o contexto histórico da criação da Lei de Contravenções Penais, analisemos o art. 24, como exemplo a fim de ilustrar um Estado policialesco, da referida Lei que considera crime de contravenção penal fabricar, ceder ou vender gazua ou instrumento empregado usualmente na prática de crime de furto sob pena de prisão simples, de seis meses a dois anos, e multa, de trezentos mil réis a três contos de réis.

No artigo supra mencionado, temos que o Estado antecedendo um possível crime, tipifica como sendo contravenção penal o simples fato de fabricar, ceder ou vender gazua ou instrumento empregado usualmente na pratica de crime de furto, ou seja, há claramente a prisão de um individuo que não agiu, mas possui instrumentos de um hipotético crime.

Há, evidentemente, a inversão do ônus da prova, isto é, dever-se-ia o acusado comprovar a destinação legítima, por exemplo, de um pé-de-cabra ou que uso a gazua é devido à profissão de chaveiro para não ser um contraventor. Nos dizeres de Damásio de Jesus, ${ }^{54}$ não seria possível, por exemplo, o fato de um eletricista emprestar a terceiro uma chave de fenda ou de um encanador fabricar um alicate para uso próprio.

Dessa forma, toda evolução para o alcance de um Estado Democrático de Direito poder-se-ia ruir se a proporcionalidade fosse aplicada de maneira irrestrita, vez que a admissão de provas ilícitas feriria a Carta Republicana de 1988. Além do mais, poderíamos presenciar o retorno de um Estado policialesco que, para evitar uma possível

\footnotetext{
52 HISTÓRIA do Brasil. 2ed. São Paulo: Empresa Folha da Manhã e Zero Hora/RBS Jornal, 1997.

53 SILVA, José Afonso da. Curso de direito constitucional positivo. 24. ed. São Paulo: Malheiros, 2005.

54 JESUS, Damásio de. Lei das contravenções penais anotada. 8. ed. São Paulo: Saraiva, 2001.
} 
prova inadmissível, passaria a antecipar atos, prever ações por meio de vigilância, repressão.

Ter-se-ia uma inversão do ônus da prova em que o cidadão deveria provar que não estaria cometendo um ato ilícito, as liberdades seriam cerceadas e o Estado poderia tornar-se um regulador, violador de inviolabilidades, da intimidade.

Por fim, feriríamos diversos princípios elencados anteriormente dentre eles os basilares de um Estado Democrático de Direito como o da constitucionalidade, pois haveria exclusão da supremacia da Carta Magna; o da vontade inicial do legislador constitucional; o da democracia representativa e participativa na construção de leis válidas e eficazes, que seriam negadas; o da legalidade que passaria a não ter valor algum perante sua rejeição; e o da segurança jurídica perdendo sua eficácia.

\subsection{Do ferimento da presunção de inocência}

Diante de um Estado policialesco, as liberdades passariam a ser cerceadas, pois o ente, responsável pela garantia da ordem e limitado pelas garantias constitucionais dos cidadãos, passaria a vigiar, punir antecipadamente, violar inviolabilidades. As pessoas necessitariam de ter que provar o não cometimento de atos delituosos, haveria a inversão do ônus da prova.

A efetiva aplicação da proporcionalidade para sanar as provas obtidas por meios ilícitos poderia passar a fazer parte do cotidiano e muitos atos abusivos cometidos por um Estado autoritário seriam justificados.

Por exemplo, feita uma rede de grampos telefônicos ilegais porque o Estado suspeita de determinados indivíduos, cabível seria o uso de tal meio com intuito de justificar-se o fim, sem a devida autorização judicial. Ora, temos claramente um ferimento cabal ao princípio da presunção de inocência do âmbito constitucional e do processo penal.

Declara a Carta Republicana em seu art. 50, inciso LVII: "ninguém será considerado culpado até o trânsito em julgado de sentença penal condenatória" ${ }^{55} \mathrm{O}$ referido princípio já estava previsto na Declaração dos Direitos Humanos do Homem e do Cidadão da França, de 26 de agosto de 1789, em que no seu art. $9^{\circ}$ previa: "Todo acusado

55 Atualmente, o disposto no art. 393, II do Código de Procedimento Penal, que declara o lançamento do nome do réu no rol dos culpados em decorrência de efeitos de uma sentença penal condenatória recorrível, tem-se a inserção do nome de um acusado no rol dos culpados, indevidamente, pelo fato de não se haver o julgamento pleno e impassível de recurso, vez que a mencionada sentença poderia ser recorrida. Isso nega e fere o princípio da inocência por não manter a dignidade do acusado e seu estado de não culpabilidade até o trânsito em julgado da sentença penal condenatória, conforme aduz a Carta Magna em seus direitos e garantias fundamentais. 
é considerado inocente até ser declarado culpado e, se julgar indispensável prendê-lo, todo o rigor desnecessário à guarda da sua pessoa deverá ser severamente reprimido pela lei”.

E a Convenção Americana de Direitos Humanos em seu art. 8.2., como garantia judicial, preconiza que "toda pessoa acusada de um delito tem direito a que se presuma sua inocência, enquanto não for legalmente comprovada sua culpa”. (...)

Luiz Flávio Gomes ${ }^{56}$ explica que do princípio da presunção de inocência emanam duas regras: a regra de tratamento e a regra probatória. A primeira está relacionada ao acusado que não pode ser tratado como condenado antes do trânsito em julgado final da sentença condenatória, conforme no art. $5^{\circ}$, inciso LVII da Constituição Federal brasileira. Assim, o acusado deve receber um tratamento digno evitando qualquer antecipação de juízo condenatório ou de reconhecimento da culpabilidade do imputado, ser tratado com dignidade como não participante do fato imputado até a sentença em trânsito em julgado.

A segunda regra, por sua vez, está relacionada à presunção de inocência quanto ao âmbito probatório, ou seja, caberia a quem acusa, o ônus de provar legal e judicialmente a culpabilidade, a responsabilidade, do imputado. No processo penal, não existe a presunção de veracidade dos fatos narrados, não existe a confissão ficta, inclusive quando o acusado não contesta os fatos expostos em peça acusatória, logo tudo que se for alegado, deve estar devidamente comprovado, caso contrário, o acusado deverá ser absolvido por falta de provas, e ter sua inocência intocada. Estar-se-ia, portanto, ferindo evidentemente essas duas regras emanadas do princípio.

No entendimento de Alexandre de Moraes, ${ }^{57}$ a presunção de inocência é um dos princípios basilares do Estado de Direito como garantia processual penal, visando à tutela da liberdade pessoal, assim, o Estado tem a necessidade de comprovar a culpabilidade do indivíduo, constitucionalmente presumido inocente, sob pena de voltarmos ao total arbítrio estatal.

Conforme aduz Mirabete, ${ }^{58}$ no princípio da não-culpabilidade, o acusado é inocente durante todo o desenvolver do processo e somente será considerado culpado quando houver uma sentença final e definitiva declarando o estado de culpabilidade de cometimento determinado delito.

Dessa forma, o princípio da presunção de inocência é, para Mirabete, uma proteção ao acusado com o seguinte: "a restrição à liberdade do acusado antes da sentença definitiva só deve ser admitida a título de medida cautelar, de necessidade ou conveniência, segundo estabelece a lei processual; o réu não tem o dever de provar a sua inocência; cabe

\footnotetext{
56 GOMES, Luís Flávio; MAZZUOLI, Valério de Oliveira. Comentários à Convenção Americana sobre Direitos Humanos: Pacto de San José da Costa Rica. 2. ed. São Paulo: Revista dos Tribunais, 2009. v. 4.

57 MORAES, Alexandre de. direitos humanos fundamentais: teoria geral. 8. ed. São Paulo: Atlas, 2007.

58 MIRABETE, Julio Fabrini. processo penal. 18. ed. São Paulo: Atlas, 2008.
} 
ao acusador comprovar a sai culpa; para condenar o acusado, o juiz deve ter a convicção de que ele é responsável pelo delito, bastando, para sua absolvição, a dúvida a respeito da sua culpa (in dubio pro reo)".

Cabe ressaltar que no decorrer de todo o procedimento, em regra, o acusado deverá estar com paridade de armas para se defender ante os princípios do contraditório e da ampla defesa, sendo assim, uma sentença final condenatória declarando culpado o réu, presume-se que houve seguimento ao devido processo legal, logo o julgamento, em tese, seria justo.

E ainda, tendo em vista que a natureza relativa da presunção de inocência é iuris tantum, é uma presunção que admite prova em contrário, logo pode o acusado defender-se das acusações provando sua não culpabilidade, protegido pelo direito de ampla defesa e do contraditório, possibilitando que se haja um procedimento adequado para a verificação jurisdicional da real ocorrência de um delito e de sua autoria.

De outro lado, com um Estado antecipadamente taxando os ditos suspeitos em criminosos, utilizando-se de meios ilegais de obtenção de provas a fim de investigar, violando intimidades, ter-se-ia, claramente um ente máximo valendo-se de seu poder para massacrar princípios constitucionais e processuais penais, dentre eles o princípio do estado de inocência.

Haveria claramente a negação direta do princípio da inocência, pois o Estado apontando um indivíduo sob necessidade de provar que não cometera determinado delito, ou até mesmo impondo uma escuta telefônica de maneira ilegal, podendo utilizá-la em um processo, teremos a exclusão não só do estado de não culpabilidade do acusado, como também de seus direitos de ampla defesa, do contraditório e de todo um devido processo legal.

São sábias as palavras do jurista Gustavo Badaró ${ }^{59}$ quando afirma que “a presunção de inocência assegura a todo e qualquer indivíduo em prévio estado de inocência, que somente pode ser afastado se houver prova plena do cometimento de um delito, é uma presunção política que garante a liberdade do acusado diante do interesse coletivo à repressão penal”.

Assim, o princípio da presunção de inocência exige que se tenha para toda condenação a comprovação plena e evidente feita pela acusação por meios das provas, desde que respeitem o princípio da legalidade e os demais princípios de um Estado Democrático de Direito, logo é ilegal a condenação inexistindo as devidas comprovações de autoria e delito, caso contrário, estaríamos diante dos atos arbitrários do Estado que,

59 BADARÓ, Gustavo H. R. Ivahy. Direito processual penal. Rio de Janeiro: Elsevier, 2008. t. 1. 
sendo policialesco, estaria de acordo com todos os tipos de violações ao individuo digno e inocente.

Dessa forma, não cabe ao Estado, com todo o seu poder, valer-se da proporcionalidade e anular princípios essenciais que é o da presunção da inocência afirmando ser seu interesse de maior relevância em detrimento de um injustiçado.

\subsection{Do ferimento aos direitos fundamentais ${ }^{60}$}

Outro caso, que a adoção da proporcionalidade quanto às provas ilícitas traria riscos, seria a obtenção de provas por meio de violação de direitos fundamentais, garantidos constitucionalmente.

Demonstrado por Ada Pellegrini Grinover ${ }^{61}$ teríamos, assim, uma ilicitude material na obtenção dessas provas e a sua inadmissibilidade processual na visão da inconstitucionalidade. Visa-se proteger a liberdade e a dignidade humana.

Ada Pellegrini Grinover declara que em sendo a ilicitude um conceito geral do direito, e não conceito especial de algum dos ramos, o princípio de que o que é nulo é inválido é também geral: e assim, para sustentar-se a inadmissibilidade de uma prova em juízo, basta o fato de que tenha sido ela obtida ilegalmente, violando-se normas jurídicas de qualquer natureza".

E ainda, essa exclusão das provas obtidas através de um procedimento ilegal não seria o caso da consequência de uma atitude meramente formalista, mas no sentido de que a posição formalista existe para a proteção de princípios superiores como na defesa de direitos e garantias positivados para a tutela da personalidade humana.

${ }_{60}$ A professora Ada Pellegrini Grinover diferencia, com grande propriedade, os conceitos de liberdades públicas e os direitos do homem. Para a jurista todas as liberdades são públicas pelo fato da obrigação de respeitá-las, é imposta pelo Estado e pressupõe sua intervenção. Assim, o que torna pública uma liberdade é a intervenção do Poder, pelo direito positivo. As liberdades públicas são direitos do homem que o Estado, através de sua consagração, transferiu do direito natural ao direito positivo, é o reconhecimento dos direitos do homem pelo direito positivo. Os direitos do homem, por seu lado, possuem uma origem jusnaturalista, constituem conceito que prescinde do reconhecimento do direito positivo, existindo ainda que a legislação não os estabeleça nem os assegure. Grinover defende que a diferença também existe quanto ao conteúdo das liberdades públicas e dos direitos do homem. A partir do século XVIII, os direitos do homem passaram por uma evolução que fez com que as liberdades em sentido estrito (negativas) fossem paulatinamente se ampliando, para também abrangerem direito a prestações positivas. Tais direitos não constituem liberdades "stricto sensu". Assim sendo, nem todos os direitos do homem, ainda que reconhecidos pelo direito positivo, são suscetíveis de fundamentar uma liberdade pública “strictu sensu”. (GRINOVER, Ada Pellegrini. Liberdades Públicas e Processo Penal - As Interceptações Telefônicas. São Paulo: Saraiva, 1976).

61 GRINOVER, Ada Pellegrini. Liberdades públicas e processo penal: as interceptações telefônicas. São Paulo: Saraiva, 1976. 
Dessa forma, corre-se o risco de violar normas jurídicas de qualquer natureza a fim de se alcançar algum objetivo esmagando, por exemplo, a personalidade humana, razão esta que se instituem certos formalismos.

Para Irajá Pereira Messias, ${ }^{62}$ nesse mesmo sentido, temos que a prova ilícita está atrelada aos conceitos de liberdades públicas, ${ }^{63}$ portanto, devem ser "intocados, preservados e protegidos pela lei: intimidade, inviolabilidade de domicílio, de comunicação e de correspondência, a prova obtida pela tortura física ou moral, e outras tantas modalidades que alcançam e vulneram a intimidade humana". Para o jurista, a prova ilícita é toda e qualquer prova que tenha violado direitos inaceitáveis de serem feridos como os supra mencionados.

É com grande razão que Irajá Pereira Messias defende a coexistência, o equilíbrio dos direitos, "exigindo-se deles que coexistam em harmonia e com critérios de proporcionalidade. Essa proporcionalidade, no entanto, não pode declinar do geral em favor do particular porque, diferentemente, seria criar perigoso precedente, criando também ensanchas ao deletério hábito de generalizar fatos e tornar-se hábito corriqueiro de nossas práticas".

Temos também, com grande sapiência, a defesa por parte de Winfried Hassemer ${ }^{64}$ acerca das ameaças às garantias no processo penal e aos direitos fundamentais, isto é, tem-se minimizado as garantias em três fases.

A primeira, de acordo com Hassemer, tem em comum a relação entre processo penal e a Constituição em que a luta da criminalidade se dá pela limitação aos direitos fundamentais. E as teorias basilares da Constituição e do Processo Penal advêm do iluminismo, excluindo-se, portanto, o direito natural juntamente com as leis e a justiça que passaram a ser construídas pelo princípio do contrato social, dos interessados. Assim, temos o Estado como garantidor dos limites da liberdade, tarefa esta desempenhada de forma derivada, vez que as pessoas seriam incumbidas pela originária pelo ideário iluminista. O Estado tem, portanto, o dever de restringir as esferas das liberdades dos indivíduos para que um não ultrapasse a do outro.

Nesse sentido, a tarefa do Direito Penal, pelas mãos do Estado, age como limitador da liberdade por meio da repressão. Não em sentido negativo, mas no sentido de se ter a segurança da prevalência da liberdade graças ao Direito Penal. Os direitos fundamentais servem para os cidadãos reconhecerem quais as intervenções que ele não precisa suportar como manter o Estado longe de sua liberdade, assim, é um direito de

\footnotetext{
MESSIAS, Irajá Pereira. Da Prova Penal. 3ed. Campinas: Impactus Editora, 2006.

63 Vide nt. 58.

${ }^{64}$ HASSEMER, Winfried. Processo penal e direitos fundamentais. In: PALMA, Maria Fernanda (Coord.). Jornadas de direito processual penal e direitos fundamentais. Editora Almedina, 2004.
} 
defesa, defesa esta contra o clássico Leviathan, considerado como o sustento e ao mesmo tempo uma ameaça. Hassemer afirma que os "direitos fundamentais servem para colocar grilhões a este Leviathan, para o confinar no seu âmbito".

Os direitos fundamentais, enquanto direitos de defesa, são essenciais para o Direito Penal, vez que as cominações penais constituem restrições às liberdades dos cidadãos, as investigações no processo penal ameaçam igualmente as liberdades, o patrimônio e a honra dos cidadãos, o mesmo com a pena.

Dessa forma, o jurista eleva a necessidade de uma Constituição reagindo contra o papel mencionado do Estado e do Direito Penal, pois assegura os direitos fundamentais relacionados com o Direito Penal, é a ação do princípio da legalidade em obediência à Lei Maior.

A segunda fase abordada por Winfried Hassemer é uma evolução caracterizada pela diminuição das garantias, por uma ampliação do Direito Penal e por um aumento do poder do Estado. As razões para essa evolução são duas, a primeira, a erosão normativa em que as normas sociais, as cotidianas e não escritas, estariam postas à erosão, perdendo eficácia.

Essa erosão teria como efeito um enfraquecimento da orientação normativa, assim, haveria perda da sua função de nortear, pois estabelecem aquilo que se pode confiar, escapa-se, portanto, a segurança normativa. A segunda é a sociedade do risco em que as sociedades ocidentais encontram-se diante de grandes riscos, como graves abusos, destruição do ambiente a nível internacional, criminalidade organizada, entre outros.

Dessa forma, os grandes riscos caracterizam-se como não domináveis, vagos, logo a população passa a ter seu medo aumentado e uma necessidade de controle. Diante dessa ameaça do risco, a população carece de orientação, segurança normativa, por isso em pânico reage e encurralada, as sociedades do risco tendem para uma agravação dos meios repressivos e para uma antecipação do controle.

Hassemer expõe criticamente um procedimento à criminalização antecipada, a criminalização na fase prévia à lesão de um bem jurídico, como ocorre nos crimes de perigo abstrato, comum no Direito Penal moderno, em que não existe uma lesão real do bem jurídico, nem ele posto concretamente em perigo, basta a existência da ação abstratamente perigosa. Acrescenta, o ilustre jurista, "há vantagens para a perseguição penal, pois não há muito a provar".

No âmbito do Direito Processual Penal o caminho é semelhante, pois, conforme aduz Winfried Hassemer, as reformas do processo penal concentram-se nas últimas décadas na fase de investigação, momento em que temos o instrumento de controle, como o caso de observação policial, escutas secretas em habitações, agentes infiltrados entre outros. Discutem-se problemas como o caso de ter uma investigação confidencial, pois se o investigado tem ciência do ato, de nada adianta o sigilo, logo o visado não 
terá conhecimento. Outro problema é o fato dos instrumentos atingirem necessariamente terceiras pessoas como agentes infiltrados, escutas telefônicas, portanto, a vigilância não tem afetação somente aos suspeitos, mas ao seu círculo de relações. É um ferimento à inocência em fase da investigação e ainda o investigado tem de suportar uma possível prisão preventiva ou sua vigilância pela polícia com base na suspeita. O jurista clarifica que os instrumentos modernos de investigação atingem igualmente pessoas não suspeitas.

Por fim, Hassemer, em sua terceira fase, coloca que o Estado não é mais o Leviathan, tornou-se um parceiro no combate aos riscos e contra a criminalidade, assim, os direitos fundamentais não têm a mesma eficácia na defesa contra o Estado deixando de cumprir com sua função, tornando-se um obstáculo.

Dessa maneira, o Direito Penal não é mais a ultima ratio, mas um módulo auxiliar, uma prima ratio ou sola ratio, nas palavras do jurista. Portanto, o Direito Penal seria o instrumento idôneo para o domínio dos grandes riscos e explora-se um novo paradigma, o paradigma da prevenção.

Assim sendo, uma saída ilustrada por Hassemer foi o caso de furto de BMW e Mercedes que eram exportados para a Jordânia, Albânia e havia Máfias que os introduziam na Polônia. Chegou-se a duas vias: uma seria a realização de escutas, investigação dissimulada; a outra seria a utilização de um dispositivo de bloqueio de automóveis. Optou-se pela segunda e a questão foi resolvida sem qualquer investigação dissimulada, assim, não se recorreu ao meio repressivo, mas ao eficiente.

Dessa forma, ao invés de se partir diretamente para o meio repressivo, que fere as liberdades, os direitos de defesa contra o Estado, poder-se-ia buscar outras maneiras anteriores a isso como um melhor controle na Administração, ou do Direito Administrativo, ou um Estado eficiente, poder-se-ia buscar o problema na raiz e não em suas consequências.

As formalidades, por vezes, existem para se manterem afastadas as condutas possivelmente maléficas a uma sociedade e a impossibilidade de admissão de provas por meio ilícito está descrita na Constituição Federal Brasileira e no Código de Processo Penal Brasileiro não só por mero formalismo, mas com o intuito afastar as provas vedadas e de proteger as liberdades e a dignidade humana.

O legislador prevendo possíveis arbitrariedades do Estado visou evitar que violações aos direitos fundamentais ocorressem com a formalização dos direitos e garantias fundamentais, os direitos humanos positivados, cujo objetivo é proteger e agasalhar os indivíduos juridicamente contra os atos e abusos do Estado.

Hassemer explorou muito bem a necessidade de se colocar grilhões ao Leviathan por meio dos direitos fundamentais, pois a atuação estatal repressiva só pode ser contida pela ciência clara e evidente de seus limites devidamente escritos. 
A utilização da proporcionalidade para balizar e abafar certos direitos em escolha de outros é afrouxar os grilhões que definem o limite de movimentação do Estado e permitindo-se a ponderação de princípios com base na proporcionalidade, podese acabar ferindo direitos e garantias fundamentais trazendo prejuízos irreparáveis aos feridos e devolver as forças imensuráveis do antigo Estado Leviathan.

Conclusão

Diante de toda a exposição demonstrou-se que a prova tem grande relevância no desenrolar e corroboração de fatos do processo. São por meio das provas que as partes, respeitados os princípios do contraditório e da ampla defesa, podem demonstrar os fatos ocorridos no passado e fazer com que o juiz, à luz do livre convencimento, possa chegar à verdade, formada nos limites do material probatório recolhido e fornecido pelas postulações alheias a ele, evidentemente, dentro dos ditames legais.

Todavia, há ocasiões em que a maneira de se obter determinada prova a fim de incluí-la no processo penal ocorre de forma ilícita, isto é, ferindo norma de direito material, assim, a Constituição Federal e o Código de Processo Penal extirparam a possibilidade de provas ilícitas no curso do processo, salvo por uma exceção, as prova ilícitas pro reo visando a legítima defesa dos direitos fundamentais do acusado injustamente.

Haja vista a explícita inadmissibilidade das provas ilícitas no ordenamento jurídico brasileiro, correntes doutrinárias passaram a contornar as vedações dessa espécie de prova valendo-se da proporcionalidade, ou seja, o sopesamento de interesses conflitantes, o que torna a questão delicada, pois teríamos um subjetivismo exacerbado e uma fragilidade na segurança jurídica.

Ademais, a proporcionalidade como forma de sopesamento de interesses conflitantes poderia dar forças a um Estado policialesco, pois tendo a chance de se ponderar qual valor prevalecerá sobre o outro, é permitir que o ente máximo administrativo regule segundo suas próprias vontades e não de acordo com os dizeres legais. É autorizar, assim, uma repressão que, em se aceitando provas ilícitas, automaticamente consente-se no ferimento ao próprio Estado Democrático de Direito, ao princípio da legalidade, da constitucionalidade e da justiça social.

Além disso, admitir uma proporcionalidade indiscriminada acerca das provas ilícitas é ferir diretamente à presunção de inocência, porquanto um Estado policialesco, repressivo, teria poderes para investigar, violar intimidades agasalhado pela ponderação de interesses, logo teríamos uma perseguição penal em que não se teria o que provar, portanto, uma inversão do ônus da prova para o suspeito.

Por fim, a adoção da proporcionalidade poderia trazer riscos quanto ao ferimento dos direitos fundamentais na medida em que o Estado alegando uma luta pela 
contra criminalidade, faria uma supressão aos direitos fundamentais. Ou seja, suas rédeas sob a forma de leis afrouxar-se-iam permitindo que o clássico Leviathan surgisse com força ameaçando as liberdades dos cidadãos.

Desvirtuar a proporcionalidade permitindo que o Estado assuma poderes dantes limitados por leis e princípios, traz riscos a toda uma sociedade que poderá encontrar um ente máximo policialesco e violador de inviolabilidades, hoje, protegidas sob a forma de direitos fundamentais.

Toma-se as palavras do juiz americano Holmes, citado pela ínclita jurista, Ada Pellegrini Grinover, ${ }^{65}$ "é um mal menor o de que um ou outro criminoso possa fugir à justiça do aquele de autoridades públicas desempenharem uma parte ignominiosa na busca de provas por meio ilícitos".

Dessa forma, conclui-se que a proporcionalidade traz sérios riscos na sua adoção pela admissão de provas ilícitas, salvo na exceçãojá mencionada. Tanto a Constituição Federal como o Código de Processo Penal são taxativos em inadmiti-las, portanto, cabe ao Estado buscar os problemas criminais em suas raízes e não nas consequências usando artifícios para contorná-los. Tampouco, pode-se valer da proporcionalidade como meio de se justificar o objetivo principal no processo penal, a verdade real.

São Paulo, junho de 2009.

\section{Referências}

ALEXY, Robert. Teoria dos direitos fundamentais. Tradução de Luís Virgílio Afonso da Silva. São Paulo: Malheiros, 2008.

ALMEIDA JÚNIOR, João Mendes de. Direito judiciário brasileiro. São Paulo: Livraria Freitas Bastos, 1960.

ALMEIDA JÚNIOR, João Mendes de. O processo criminal brasileiro. 4. ed. São Paulo: Livraria Freitas Bastos, 1959. v. 1 e 2.

ARANHA, Adalberto José Q. T. de Camargo. Da prova no processo penal. 7. ed. 3 tir. São Paulo: Saraiva, 2008.

ÁVILA, Humberto. Teoria dos princípios: da definição à aplicação dos princípios jurídicos. 9. ed. São Paulo: Malheiros, 2009.

ÁVILA, Thiago Pierobom. Provas ilícitas e proporcionalidade. Rio de Janeiro: Lumen Juris, 2007.

${ }_{65}$ GRINOVER, Ada Pellegrini. Liberdades públicas e processo penal. As interceptações telefônicas. São Paulo: Saraiva, 1976. 
AVOLIO, Luiz Francisco Torquato. Provas ilícitas: interceptações telefônicas e gravações clandestinas. São Paulo: Revista dos Tribunais, 1995.

BADARÓ, Gustavo H. R. Ivahy. Direito processual penal. Rio de Janeiro: Elsevier, 2008. t. 1.

BADARÓ, Gustavo H. R. Ivahy. Ônus da prova no processo penal. São Paulo: Revista dos Tribunais, 2003.

BARROS, Marco Antonio de. A busca da verdade no processo penal. São Paulo: Revista dos Tribunais, 2002.

CHIMENTI. Francisco. O processo penal e a verdade material: (teoria da prova). Rio de Janeiro: Forense, 1995.

COELHO, Walter. Prova indiciária em matéria criminal. Porto Alegre: Sérgio Antonio Fabris Editor, 1996.

CORREIA, Belize Câmara. O controle de constitucionalidade dos tipo penais incriminadores à luz da proporcionalidade. Porto Alegre: Sérgio Antonio Faris Editor, 2009.

ENCICLOPÉDIA Larousse Cultural. São Paulo: Nova Cultural, 1998.

SILVA, De Plácido e. Vocabulário jurídico. 24. ed. Rio de Janeiro: Forense, 2004.

ESSADO, Tiago Cintra. O princípio da proporcionalidade no direito penal. Porto Alegre: Sérgio Antonio Fabris Editor, 2008.

GOMES FILHO, Antonio Magalhães. Direito à prova no processo penal. São Paulo: Revista dos Tribunais, 1997.

GOMES FILHO, Antonio Magalhães; PRADO, Geraldo; BADARÓ, Gustavo Henrique Righi Ivahi; Santos, Leandro Galuzzi dos; BOTTINI, Pierpaolo Cruz. As reformas no processo penal. Coordenação de Maria Thereza Rocha de Assis Moura. São Paulo: Revista dos Tribunais, 2008.

GOMES, Luís Flávio; MAZZUOLI, Valério de Oliveira. Comentários à Convenção Americana sobre Direitos Humanos. Pacto de San José da Costa Rica. 2. ed. São Paulo: Revista dos Tribunais, 2009. v. 4.

GOMES, Mariangela Gama de Magalhaes. O principio da proporcionalidade no direito penal. São Paulo: Revista dos Tribunais, 2003.

GRINOVER, Ada Pellegrini. Liberdades públicas e processo penal: as interceptações telefônicas. São Paulo: Saraiva, 1976

GRINOVER, Ada Pellegrini; FERNANDES, Antonio Scarance; GOMES FILHO, Antonio Magalhães. As nulidades no processo penal. 9. ed. São Paulo: Revista dos Tribunais, 2006.

HASSEMER, Winfried. Processo penal e direitos fundamentais. In: PALMA, Maria Fernanda. Jornadas de direito processual penal e direitos fundamentais. Coimbra: Editora Almedina, 2004. 
HISTÓRIA do Brasil. 2. ed. São Paulo: Empresa Folha da Manhã e Zero Hora/RBS Jornal, 1997. HORCAIO, Ivan. Dicionário jurídico referenciado. 1. ed. São Paulo: Primeira Impressão, 2006. JESUS, Damásio de. Lei das contravenções penais anotada. 8. ed. São Paulo: Saraiva, 2001.

KHALED JÚNIOR. Salah H. Ambição de verdade no processo penal. Salvador: Jus Podium, 2009.

MARQUES, José Frederico. Elementos de direito processual penal. 1. ed. Campinas: Bookseller, 1998. v. 2 .

MELLO, Rodrigo Pereira de. Provas ilícitas e sua interpretação constitucional. Porto Alegre: Sergio Antonio Fabris Editor, 2000.

MESSIAS, Irajá Pereira. Da prova penal. 3. ed. Campinas: Impactus Editora, 2006.

MIRABETE, Julio Fabrini. Processo penal. 18. ed. São Paulo: Atlas, 2008.

MITTERMAYER, C. J. A. Tratado da prova em matéria criminal. Traduzido por Alberto Antonio Soares. Rio de Janeiro: Livraria do Editor, 1871. t. 1 e 2.

MORAES, Alexandre de. Direito constitucional. 19. ed. São Paulo: Atlas, 2006.

MORAES, Alexandre de. Direitos humanos fundamentais: teoria geral. 8. ed. São Paulo: Atlas, 2007.

RABONEZE, Ricardo. Provas obtidas por meios ilícitos. 3. ed. Porto Alegre: Síntese, 2000.

SILVA, José Afonso da. Curso de direito constitucional positivo. 24. ed. São Paulo: Malheiros, 2005 .

VISHINSKI, Andrei. A prova judicial no direito soviético. Tradução de Roberto Pereira de Vasconcelos. Rio de Janeiro: Editora Nacional de Direito Ltda., 1957

WEFFORT, Francisco C. Os clássicos da política. 13. ed. São Paulo: Ática, 2005. v. 1. 